\title{
Søknadsbasert turnustjeneste - hvem skal få jobb?
}

\author{
Ny søknadsbasert turnusordning innføres i år. Hvilke turnusleger som ansettes vil kunne ha betydning \\ for avdelingen og sykehuset over tid. For at sykehusene selv skal kunne dra mest nytte av den nye ordningen, \\ bør ansettelsene baseres på gjennomtenkte seleksjonskriterier.
}

Fra 2013 innføres søknadsbasert turnustjeneste for leger. Fordeling av turnusplasser gjennom loddtrekning forlates og nyutdannede leger må nå søke på utlyste turnusstillinger på det enkelte sykehus. Den nye ordningen medfører konkurranse om turnusplassene og risiko for å bli stående uten jobb. Samtidig får arbeidsgivere en gyllen mulighet til selv å kunne påvirke sammensetningen i sin legestall.

Søknadsbasert turnus vil i større grad tillate en kontinuitet mellom turnuslegevikariater, turnustjeneste og stilling som lege i spesialisering. Tidligere var ikke turnuslegevikariater like viktig for videre karriere, fordi turnus gjennom loddtrekning oftest ville avbryte arbeidsforholdet. Med søknadsbasert turnus vil et vikariat ved en avdeling gi større sannsynlighet for senere ansettelse som turnuslege og videre ansettelse som lege i spesialisering. Mange turnusleger vil sannsynligvis søke seg til en avdeling/et sykehus hvor de har ønske om å bli værende også etter at turnustjenesten er gjennomført. Ansettelser av turnuslegevikarer og turnusleger vil derfor i større grad være med på å definere avdelingen/sykehuset på sikt.

\section{Akseptert ukultur?}

Søknadsbasert turnus er nytt og uten etablerte rutiner for god evaluering av søkere. Mengden ressurser ved helseforetakene regnes allerede som utilstrekkelig. Det vil være vanskelig å finne tid og ressurser til å gi alle søkere en tilfredsstillende vurdering, og det kan bli fristende å ta i bruk rutiner som er blitt benyttet ved ansettelse av turnuslegevikariater. Tilbakemeldinger fra medisinstudenter og leger som har søkt turnuslegevikariater, gir inntrykk av at slike ansettelser er preget av en ukultur. Ansettelsene virker i noen tilfeller basert på bekvemmelighet og lettvinte løsninger. Personen som ansettes ser ut til å være den som i størst grad oppfyller kriterier definert ut fra bekjentskap og praktiske hensyn. Dette kan være hvor man er fra, om man har arbeidet på sykehuset tidligere, eller mer uoffisielt, hvem man kjenner på sykehuset.

Eksempler på slik ukultur er i det siste kommet frem i mediene. Stavanger universitetssjukehus har siden nyttår fått mye oppmerksomhet etter prosessen rundt ansettelser av turnuslegevikarer for sommeren 2013 (1). Prosessen var preget av uryddige rutiner, tilbud om jobb før stillinger var utlyst og av at usedvanlig mange av dem som fikk jobbtilbud var familiemedlemmer av leger ansatt ved helseforetaket.

Slike ansettelsesprosesser er ikke unike for Stavanger universitetssjukehus. Som tidligere arbeidstaker i et offentlig helseforetak og tillitsvalgt i Norsk medisinstudentforening (Nmf) har undertegnede observert og blitt fortalt om slike ansettelsesrutiner. Det negative søkelyset på akkurat Stavanger universitetssjukehus skyldes trolig at de hadde tidligere søknadsfrist enn de fleste andre sykehus, ikke at sykehuset er verre enn andre på dette området.

Denne ukulturen må man arbeide seg bort fra. Å bruke ressurser på å finne frem til de beste søkerne til turnusstillinger vil kunne gi positive ringvirkninger for avdelingen/sykehuset på sikt. Det bør derfor være en prioritert oppgave.

\section{Forhåndsdefinerte kriterier}

Norsk medisinstudentforening kom 14. april 2013 med en uttalelse om saklige kriterier for ansettelse (2). Oppsummert foreslår foreningen at arbeidserfaring fra helsevesenet og forskningserfaring bør vektlegges og at lokal tilhørighet og studiested i mindre grad bør tas $i$ betraktning. Forslagene er etter min mening fornuftig begrunnet, og mange medisinstudenter vil betrakte ansettelser basert på slike kriterier som rettferdige. I forkant av intervjuer blir utfordringen for arbeidsgiver å velge blant søkere med rimelig lik bakgrunn.

Jeg mener at fagkunnskaper bør stå sentralt ved ansettelser av leger. Vurdering av slik kunnskap kan være krevende, siden tre av fire medisinske fakulteter i Norge ikke gir karakterer. Med den nye turnusordningen vil det være grunn til å vurdere å gjeninnføre karakterer på medisinstudiet. Ansettelsesprosessen vil forenkles om man i større grad har håndfaste utgangspunkt å basere vurderingen på. En nasjonal eksamen felles for alle turnussøkere er et verktøy verdt å utrede. I tillegg til karakterer kan attester og anbefalelsesbrev fra lærere og veiledere gi grunnlag for å vurdere fagkunnskaper. Attester tillater også tilbakemelding for «myke» ferdigheter, som kommunikasjon og empati.

Når de faglig beste kandidatene er plukket ut, bør neste punkt være å se på hvilke andre egenskaper og erfaringer kandidatene har. Dette bør holdes opp mot hvilke behov norsk helsevesen og det spesifikke sykehuset har. Norsk medisinstudentforening nevner forskningserfaring, som jeg helhjertet støtter. Jeg vil også legge til ledererfaring og erfaring innen administrasjon/økonomi. Den nyopprettede Helsetjenesteaksjonen understreker behovet for slik kompetanse i helsevesenet. Sett i lys av vår tids globale fedmeepidemi og forekomsten av andre livsstilssykdommer, bør også kompetanse innen forebyggende medisin telle positivt.

Til sist bør søkerens erfaring fra arbeid på sykehus, slik som hospitering, praksis og/eller turnuslegevikariater, vurderes. Om arbeidet er lønnet eller ikke, mener jeg ikke bør være av betydning. Slik erfaring bør ses som et supplement til allerede gode søknader, heller enn et hovedkriterium. Arbeidserfaring bør vektlegges i slutten av en seleksjonsprosess, og ikke i starten bare fordi det er lettere å sile ut søkere etter antall uker arbeidserfaring. Står det derimot mellom to søkere med tilnærmet lik bakgrunn/CV, vil nok de fleste anse det som akseptabelt at arbeidserfaring blir utslagsgivende.

Med innføringen av søknadsbasert turnustjeneste er det et sterkt behov for å få utviklet rutiner som tillater en god og rettferdig vurdering av et stort antall søkere. Jeg håper sykehusene ser det potensielle utbyttet ved å bruke ressurser på å finne frem til den beste søkeren.

\section{Kristian Hamandsen \\ hamandsen@gmail.com}

Kristian Hamandsen (f. 1984) er medisinstudent ved Semmelweis Universitet, Budapest og har verv i Norsk medisinstudentforening.

Forfatter har fylt ut ICMJE-skjemaet og oppgir ingen interessekonflikter.

\section{Litteratur \\ 1. Storvik AG. Legers barn fikk 8 av 12 jobber. Dagens medisin 6.2. 2013. www.dagensmedisin no/nyheter/legers-barn-fikk-8-av-12-jobber/ (19.5.2013) \\ 2. Norsk medisinstudentforening. Uttalelse fra Norsk medisinstudentforening om ansettelser i turnustjenesten for leger. 14.4.2013. http://legeforeningen.no/Student/ Norsk-medisinstudentforening/Nyheter/2013/ Uttalelse-fra-Norsk-medisinstudentforening om-ansettelser-i-turnustjenesten-for-leger/ (19.5.2013).}

Mottatt 3.4. 2013, første revisjon innsendt 21.5. 2013, godkjent 21.5. 2013. Medisinsk redaktør Hanne Støre Valeur.

Publisert først på nett. 